\title{
Banking law as the complex branch of legislation
}

\author{
Elena Nikolaevna Pastushenko ${ }^{1 *}$, Natalia Vladimirovna Neverova $^{1}$, Elena Vladimirovna \\ Kornukova $^{2}$, and Larisa Nikolaevna Zemtsova ${ }^{3}$ \\ ${ }^{1}$ Saratov State Academy of Law, Chair of financial, banking and customs law named after Professor \\ Khimicheva Nina Ivanovna, Saratov, Russia \\ ${ }^{2}$ Saratov State Academy of Law, Chair of Constitutional Law named after Professor Farber Isaac \\ Efimovich, Saratov, Russia \\ ${ }^{3}$ President of general jurisdiction court (emeritus), Saratov, Russia
}

\begin{abstract}
The objective of the present research is the formation of the concept of teaching banking law as the interdisciplinary subject of the Master's degree in Economics and Law in higher educational institutions. The work used the dialectic and technical methods that allowed showing the interrelation and mutual influence of the various aspects of the banking law as the interdisciplinary subject in the higher educational institutions. The comparative and legal method was used for revealing the stages of the legal regulation of the banking system of the Russian Federation and the formation of the banking law as the complex branch of legislation. The inductive method was applied when analyzing the Russian legislation with regard to the status of the Central Bank of the Russian Federation, lending institutions, bank operations and transactions and deals from the point of view of client-oriented approach and protection of consumers' rights when obtaining financial services. The most important result of the present research is the grounding of advisability to teach the banking law in the higher educational institutions as the interdisciplinary subject of the Master's degree in Economics and Law. This offer was introduced basing upon the position of the Theory of the state and law and the sectoral science of Financial Law to consider the banking law as the complex branch of legislation that allows characterizing the offer made as a result characterized by the scientific novelty having the scientific and theoretical significance for the further scientific discussions regarding the role of the complex educations in law, improvement of the law-making, law-enforcement and law-interpretive activity of the Central Bank of the Russian Federation and also the day-to-day update of the legislation due to the changing realias, performing works on education in the law and financial literacy, improvement of client-oriented approach when providing banking services and protection of rights and legal interests of the consumers of financial services.
\end{abstract}

Keywords: role of banking law in the system of law, teaching of banking law as interdisciplinary subject

* Corresponding author: past en@mail.ru 


\section{Introduction}

Under conditions of 2020-2021 caused by the pandemic of COVID-19 virus the urgency of the financial stability, qualitative and delay-free rendering of financial services by the banks, including also the digital format, increased as well as the acceptance of the regulatory norms by the Central Bank of the Russian Federation. This stipulated the increased attention to the adequacy of the legal regulation of the banking activity and the scientific interest to the place of the banking law in the system of law. In the modern scientific, study and methodological literature the fair attention is paid to the grounding of the consideration of the banking law as the complex branch of legislation. The abovementioned requires the improvement of teaching of the banking law as the complex branch of legislation from the perspective of the interdisciplinary subject of the Master's degree that includes the public legal and private public aspects.

In the modern social and economic and political and legal realias of the Russian state and the society the tendencies of development of the banking legislation and regulatory enforcement practice in the banking legal relations show the consolidation of role of banking activity in the financial activity of the state and municipal entities that appears in the extension of the bank product line and the demand for them including the digital format, increase of significance of the protection of rights and legal interests of the consumers of bank services and the necessity to perform works to increase the financial literacy. The legislative regulation of the status of entities of the banking legal relations in Russia began on December 02, 1990 when two laws of the RSFSR were passed: The Law of the RSFSR No. 394-1 dated December 02, 1990 "On the Central Bank of the RSFSR (Bank of Russia)" and the Law of the RSFSR No. 395-1 dated December 02, 1990 "On banks and banking activity in the RSFSR". The mentioned laws of the RSFSR in the middle of the 90s of the $\mathrm{XX}$ century were given in the new revision as the federal laws: this refers to the Federal law "On the Central Bank of the Russian Federation (Bank of Russia)" - as the revised Federal law No. 65-FZ dated April 26, 1995 (ceased to be in force due to the pass of the current Federal law No. 86-FZ dated July 10, 2002) and the Federal law "On banks and banking activity" - as the revised Federal law No. 17-FZ dated February 03, 1996 (still in force). Therefore, the scholarly comprehension of the 30-year experience of organization and functioning of the two-level banking system of the Russian Federation that corresponds to the requirements of the market economy is of high demand from the scientific and theoretical and practical positions.

In the beginning of the 2000s due to the new realias in the national science of the theory and the state and law the discussion of the system of law continued and the idea was expressed regarding the ratio of the branch of law and branch of legislation and the banking law was characterized as the complex branch of legislation $[1,2]$, and this started to develop also in the sectoral science of financial law $[3,4]$. It should also be mentioned that the scientific idea was expressed about the banking law as the complex branch of law [5] that was not supported by the Saratov school of the theory of state and law [6] and Saratov school of financial law named after Professor Khimicheva [7] that supported the idea of the banking law as the complex branch of legislation. The mentioned approaches are important to study the financial law as the branch of law and taxation, budget law as subbranches of financial law [8-12]. The study of the public and private aspects of the banking law [13-15] seems perspective. The positioning of the banking law as the complex branch of legislation allows presupposing the teaching of the banking law as the interdisciplinary subject with the engagement of specialists of the various scientific specialties: economy, theory of state and law, constitutional law, administrative law, financial law, informational law, civil law, criminal law, prosecutor's supervision, etc. This approach is different by its novelty and can be recommended for the Master's degree in higher educational institutions. The hypothesis of the present research is 
to consider the banking law in educational purposes as the interdisciplinary subject of the Master' degree in Economic and Law in higher educational institutions. The objective is to develop a concept of the teaching of the banking law in the higher educational institutions as the interdisciplinary subject of the Master' degree. The tasks are to reveal and give a brief description of the urgent issues of the banking law as the interdisciplinary subject.

\section{Methods}

Dialectic and technical methods allowed showing the interrelation and mutual influence of the various aspects of the banking law as the interdisciplinary subject in higher educational institutions. The comparative and legal method was used to reveal the stages of the legal regulation of the bank system of the Russian Federation and the formation of the banking law as the complex branch of legislation. The inductive method was applied when analyzing the Russian legislation with regard to the status of the Central Bank of the Russian Federation, lending institutions, bank operations and transactions and deals from the point of view of client-oriented approach and protection of consumers' rights when obtaining financial services [16-18].

\section{Results and discussion}

The consideration of the banking law as the complex branch of legislation is observed in the published papers, modern study and methodological literature [19-21]. The proposed approach to banking law teaching as the interdisciplinary subject the Master's degree in Economics and Law allowed making more profound some particular aspects of the taught subjects: Economics, Theory of state and law, Constitutional law, Administrative law, Financial law, Information law, Criminal law, Prosecutor's supervision and improving the competences of the students. From the economic position, it seems important to show the role of banks in the social and economic development of the Russian state.

The contribution of the theory of state and law in the analysis of the specified problems is of great relevance from the point of view of the methodology with respect to the system of law. The constitutional law provides insight into the legal understanding of the constitutional framework of the banking activity including the study of the constitutional amendments 2020 that develop the principle of accountability of the Central Bank of the Russian Federation to the State Duma by enshrining in Article 103 of the Constitution of the Russian Federation the powers of the State Duma to consider the annual reports of the Bank of Russia that is formalized in the Article 5 of the Federal law No. 86-FZ dated July 10, 2002 "On Central Bank of the Russian Federation (Bank of Russia) and transferred to the constitutional and legal level as proved to be positive. The study of the administrative and legal aspects of the banking law as the complex branch of legislation is directed to the processes of management optimization from the regulatory authority - Central Bank of the Russian Federation, increase of quality of the control and supervision activity on the financial market.

Financial law could pay more attention to the bank loan as a link of the financial system of the Russian Federation, financial control of the activity of lending organizations, lawmaking function of the Bank of Russia and regulatory acts of the Bank of Russia as the source of financial law, public discussion of the concept of "Digital ruble" offered in the Report of the Bank of Russia for public consultations "Digital ruble" published on the official site of the Bank of Russia on October 13, 2020.

In the conditions of the digital economy, the study of the information law is of great relevance with respect to the rendering of services by the banks in the digital format, providing the reports by the bank in the digital format and functioning of the personal account 
of banks on the site of regulatory authority. Private and legal aspects of the banking law as the complex branch of legislation can help to study the problems of the civil law. The criminal law reveals the problems of the criminal and legal protection of the banking relations. Paying special attention to the study of the theory of state and practice of the prosecutor's supervision in the field of money-and-credit relations is directed to the implementation of the practiceoriented approach in the study.

\section{Conclusions}

The performed research allows concluding that the hypothesis is confirmed, the consideration of the banking law as the complex branch of legislation serves the base of the proposed approach in the teaching of banking law as the interdisciplinary subject of the Master's degree in Economics and Law in the higher educational institutions. The perspectives of the present research are the development of the system interrelations of the mentioned subjects: Economics, Theory of state and law, Constitutional law, Administrative law, Financial law, Information law, Criminal law, Prosecutor's supervision - when teaching the banking law using the presented approach.

The present research has the scientific and theoretical significance for the further scientific discussions regarding the place of the complex educations in law as well as for improving of the law-making, law-enforcement and law-interpretive activity of the Central Bank of the Russian Federation, the day-to-day update of the legislation due to the changing realias, works on education in the law and financial literacy, improvement of client-oriented approach when providing banking services and protecting the rights and legal interests of the consumers of financial services.

The article is prepared within the frameworks of the research under financial support of the Russian Foundation of Fundamental Researches (RFFR) on the scientific research No. 18-29-16102 "Transformation of legal personality of the participants of the taxation, budgetary and public banking legal relations in the conditions of development of the digital economy", the executor of which is the Doctor in Law, Professor E.N. Pastushenko.

\section{References}

1. M.I. Baytin, D.E. Petrov, State and Law, 1, 25-34. (2003)

2. D.E. Petrov, Otrasl prava [Branch of law], in M.I. Baytin (ed.), 155-157 (Publishing House of the State Educational Institution of Higher Professional Education "Saratov State Academy of Law", Saratov, 2004)

3. T.E. Rozhdestvenskaya, Bankovskoe pravo: uchebnoe posobie [Banking law: textbook], 14-15 (Moscow, 2010)

4. E.Yu. Gracheva, Ponyatie bankovskogo prava i ego mesto v sisteme prava Rossii [Notion of banking law and its role in the Russian system of law], in E.Yu. Gracheva (ed.), Banking law of the Russian Federation: textbook (Norma: INFRA-M, Moscow, 2011)

5. G.A. Tosunyan, A.Yu. Vikulin, A.M. Ekmalyan, Bankovskoe pravo Rossiiskoi Federatsii: obshchaya chast: uchebnik [Banking law of the Russian Federation: general: textbook], in B.N. Topornin (ed.), 39 (Moscow, 2002)

6. D.E. Petrov, Dinamika sistemy prava [Dynamics of system of law], in V.L. Kulapov (ed.), Urgent problems of theory and practice of legal regulation: textbook for Master's students, 101-103 (Publishing House of Saratov State Academy of Law, Saratov, 2016) 
7. E.V. Pokachalova, E.N. Pastushenko (eds.), Predislovie [Foreword], in Banking law: textbook, 7 (Direct-Media, Moscow, 2020)

8. M.K. Borodavina, S.V. Rybakova, A.V. Savina, A.P. Khakhulina, Law Enforcement, 4(1), 75-84 (2020). https://doi.org/10.24147/2542-1514.2020.491075-84

9. O.Yu. Bakaeva, E.G. Belikov, E.V. Pokachalova, V.V. Popov, M.B. Razgildieva, Journal of Social Sciences Research, 3, 61-66 (2018).

https://doi.org/10.32861/jssr.spi3.61.66

10. E. Belikov, Tax Sovereignty of the Welfare State (Experience of The Central and Eastern European Countries), in M. Sentsova (Karaseva), E. Ruskowski, A. Paul, M. Radvan (eds.), Tax Sovereignty and the Concept of Fiscal Rule-Making in the Countries of Central and Eastern Europe: Conference Proceedings, 27-41 (Voronezh State University, Voronezh, 2018)

11. S. Mironova, Fiscal lawmaking municipalities: the experience of Russian and European states, in M. Sentsova (Karaseva), E. Ruskowski, A. Paul, M. Radvan (eds.), Tax Sovereignty and the Concept of Fiscal Rule-Making in the Countries of Central and Eastern Europe: Conference Proceedings, 180-198 (Voronezh State University, Voronezh, 2018)

12. M. Tsurkan, S. Mironova, N. Pilipchuk, Digital Transformation of Project Implementation Monitoring in the Regional Public Management, in A. Nazarov (ed.), Proceedings of the 1st International Scientific Conference "Modern Management Trends and the Digital Economy: from Regional Development to Global Economic Growth" (MTDE 2019), 81, 80-85 (2019). https://doi.org/10.2991/mtde-19.2019.15

13. T.E. Rozhdestvenskaya, A.G. Guznov, Publichnoe bankovskoi pravo: uchebnik dlya magistrov [Public banking law: textbook for Master's students], 13-22 (Prospect, Moscow, 2016)

14. T.E. Rozhdestvenskaya, A.G. Guznov, L.G. Efimova, Chastnoe bankovskoe pravo: uchebnik [Private banking law: textbook], 13-44 (Prospect, Moscow, 2020)

15. E.N. Pastushenko, L.N. Zemtsova, N.V. Neverova, E.A. Malykhina, Revista Inclusiones, 7, 45-54 (2020). Accessed on: June 25, 2021. [Online]. Available: http://www.revistainclusiones.org/gallery/5\%20VOL $\% 207 \% 20$ NUM $\% 20$ Espacio $\% 20$ y\%20Tiempo\%20en\%20el\%20Siglo\%20XXI.pdf

16. A.N. Burenin, Ekonomicheskaya Politika, 14(1), 76-91 (2019)

17. A. Golubev, O. Ryabov, A. Zolotarev, Digital transformation of the banking system of Russia with the introduction of blockchain and artificial intelligence technologies, in IOP Conference Series: Materials Science and Engineering, 940(1), 41 (2020)

18. O.Y. Kuzmina, M.E. Konovalova, Lecture Notes in Networks and Systems, 133, 189$196(2021)$

19. E.Yu. Gracheva (ed.), Bankovskoe pravo Rossiiskoi Federatsii: uchebnik dlya magistratury [Banking law of the Russian Federation: textbook for Master's Program] (Norma: Moscow, 2021)

20. G.F. Ruchkina, E.M. Ashmarina, F.K. Gizatullin, Bankovskoe pravo: uchebnik i praktikum dlya bakalavriata i magistratury [Banking law: textbook and practicum for Bachelor and Master's program] (Publishing House Urait, Moscow, 2019)

21. D.G. Alekseeva et al., Bankovskoe pravo: uchebnik i praktikum dlya bakalavriata $i$ magistratury [Banking Law: textbook and practicum for bachelor and master program], in D.G. Alekseeva, S.V. Pykhtin (eds.) (Publishing House Urait, Moscow, 2019) 